\title{
Metastatic Endometrioid Adenocarcinoma
}

National Cancer Institute

\section{Source}

National Cancer Institute. Metastatic Endometrioid Adenocarcinoma. NCI Thesaurus.

Code C8943.

An endometrioid adenocarcinoma that has spread from its original site of growth to another anatomic site. 